\title{
PRAHU OCA SRPSKE AGRONOMIJE I UTEMELJIVAČU SELEKCIJE I SEMENARSTVA
}

\author{
Mladen Mirić1^
}

\section{Izvod}

Đorđe Radić (1839-1922) je poznat kao prvi srpski doktor agronomskih nauka, mada on nije samo u tome čelni agronom Srbije, pa je to uzeto za opštu temu članka, sa posebnim osvrtom na oplemenjivanje i semenarstvo kulturnih biljaka. Radić je bio utemeljivač srpske agronauke, osnivač prvih poljoprivrednih škola, pisac kompleksne knjiške i časopisne literature, u koje je uveo crtež i kolor. Autor je prvih monografija o gajenju najvažnijih kulturnih biljaka i živine, suosnivač i čelnik srpskog Društva za poljsku privredu (DPP), njegov sekretar i urednik glasila, zatim prvi agro-prosvetitelj i agroistoričar, prvi citiran u svetskoj literaturi. Bio je član više od 60 društava, prvi je odnegovao sorte biljaka i meleze ovaca, jedan od prvih genetičara, oplemenjivača i semenara u svetu, a prvi u Srba. Prvi je među agronomima postao član Srpskog učenog društva i počasni član Srpske kraljevske akademije. Kralj Milan ga je 1889. godine odlikovao ordenom Sv. Save. Jednom rečju, Đorđe Radić je bio prvi, jedini i najzaslužniji za više od 50 prvina u srpskoj agronomiji, po čemu je jedinstven. Kada bi postojala vaga koja meri veličinu naučnika, onda bi on svakako ušao u vrh plejade najvećih ili najobrazovanijih, najkorisnijih, najproduktivnijih, najumnijih i najsvestranijih srpskih agronoma svih vremena. Članak obelodanjuje i ogrešenja o dr Radića.

Ključne reči: agronom, genetika, kultura sećanja, rodoljublje, selekcija i semenarstvo.

\section{Uvod}

Đorđe Radić rođen je u imućnoj svešteničkoj porodici 1839. u Velikom Bečkereku. Osnovnu školu završio je u rodnom mestu, a gimnaziju u Sremskim Karlovcima i Vinkovcima. Poljoprivredni fakultet upisuje na Višem poljoprivrednom institutu Kolčavka u okolini Praga. Povratkom u zemlju zapošljava se na mesto ekonoma i geometra u Subotici, kada objavljuje svoju prvu knjigu: Plug od postanka njegovog do danas, sa dodatkom koji se bavi problematikom uvođenja plugova kod nas. U Starom Bečeju, 1961. pokreće časopis Seljak, namenjen zemljoradnicima u Vojvodini. Dve godine kasnije, u Novom Sadu, je osnovao Ogledno poljoprivredno dobro, na kojem je poredio različite, strane i domaće sorte po- ljoprivrednih biljaka. Nakon položenog ispita iz Prirodnih nauka i Prirodopisa na Bečkom univerzitetu, postaje profesor niže "realke“ u Novom Sadu.

U svojoj 28. godini, 1867. na Bečkom univerzitetu, stiče zvanje doktora poljoprivrednih nauka. Njegove uspehe srpski knez Mihailo Obrenović nagrađuje slanjem na Svetsku izložbu u Pariz i usavršavanje u Francuskoj radi sticanja saznanja o savremenom gajenju živine. Povratkom u zemlju, pored znanja, Radić donosi i više primeraka rasnih kokošaka i gusaka.

U Srbiju je prešao 1869. na poziv Mihaila Obrenovića. Iako se pozivu odazvao prevashodno kao rodoljub, prelazak u Srbiju je imao delom i manje lepu pozadinu. Pored duga koji je imao prema Matici srpskoj dugovao je i izve-

Prilog u znak sećanja na dr Đorđa Radića (In memory of Dr. Djordje Radić)

${ }^{1}$ Mirić M, semenar u penziji, Institut za kukuruz Zemun Polje, Slobodana Bajića 1, Beograd

*e-mail:mladen@miric.net 
snom knjižaru iz Štutgarta. Društvo za poljsku privredu ga je ubrzo izabralo za svog sekretara i urednika lista Težak. Samo godinu dana nakon prelaska u Srbiju, u Kragujevcu, organizuje prvu Zemaljsku poljoprivrednu izložbu, a 1872., ponovo pokreće list Seljak. Iako, zbog finansijskih poteškoća nije uspeo da ostvari svoju zamisao i formira Zemljodelsku školu u Topčideru, uspeva da osnuje Zemljodelsko-šumarsku školu u Požarevcu 1872. Nakon toga, 1882. osniva Ratarsku školu u Kraljevu, gde ostaje da radi sve do penzije kao upravnik, a nakon toga u svojstvu privremenog upraviteja sve do 1892. Srpsko poljoprivredno društvo ga 1904. bira za svog sekretara, a već sledeće godine organizuje Prvu živinarsku izložbu.

Đorđe Radić je na poziv knjaza Nikole I, jedno vreme boravio i u Crnoj Gori gde je u Danilovgradu osnovao Zemljodelsku školu i uveo rane sorte krompira u široku proizvodnju. Zbog rata sa Turcima 1876. prelazi na Cetinje gde je napisao udžbenik Povrtarstvo. U znak zahvalnosti za razvoj poljoprivrede u Crnoj Gori, odlikovan je 1876. činom plemenskog kapetana. Nakon toga vratio se u Požarevac.

Umro je u Kraljevu 11.10.1922. u 84 godini života. Napisao je više knjiga i brošura, bio je osnivač, urednik i saradnik mnogih časopisa i listova. Bio je aktivni član brojnih društava i nosilac 12 odlikovanja. Izabran je za redovnog člana Srpskog učenog društva, kao i počasnog člana Srpske kraljevske akademije. Bio je nosilac ordena Sv. Save.

\section{U čemu je Đorđe Radić sve bio prvi}

Đorđe Radić je mahom poznat kao prvi doktor nauka u srpskoj agronomiji, ali on nije samo u tome bio prvi. Upravo je cilj i smisao ovoga članka da pokaže u čemu je još ovaj agrovelikan bio prvi, jedini i jedan od najvećih ili najkorisnijih agronoma svoga vremena, a i šire. Želja je da se ovim člankom dodatno osvetli "svijetli lik naše kulturne prošlosti", kako Pavićević (1966) oslovljava dr Đorđa Radića. Naime, naš agrarno-naučni preteča zaslužuje večnu pažnju kao javna ličnost, tj. stub kulture pamćenja ili podsećanja, ovaj put sa stanovišta onih njegovih dela koja su prva i jedinstvena i zahvalna za pamćenje. Takva javna ličnost vredna je pomena od strane svojih strukovnih potomaka i u vasceloj budućnosti.

$\mathrm{U}$ istraživanju su korišćeni izvori prvog i drugog reda, koje čine knjige, članci i razni dokumenti o dr Đorđu Radiću, iz kojih je na videlo izneta prošlost kao vid doprinosa kulturi sećanja. Birane su činjenice i podaci koji ukazuju na prvine - ono što je prvo, prapočetno, novo, prekretničko u njegovom opusu. Analizom obimnog istorijskog gradiva došlo se do verifikovanih svedočanstava o onome u čemu je sve ovaj agrovelikan bio prvi, jedini, jedinstven ili osobit, najznačajniji i najkorisniji ceo jedan vek, postavši tema povesnih štiva brojnih istraživača. Nažalost, osim ispoljenog zaborava Đorđa Radića posle 2. svetskog rata, imamo i pisana ogrešenja o tom uzvišenom čoveku.

Đorđe Radić nije bio samo prvi doktor agro-nauka u Srba, već i:

- Prvi agro-istoričar, autor obimne knjige o prošlosti pluga, sa brojnim i preciznim crtežima evolucije najvažnijeg zemljoradničkog oruđa (Radić, 1861).

- Prvi agronom - poliglota (po Savić, 2018., govorio je sedam jezika), pa ne možemo osporiti da je i u tom pogledu bio izuzetan.

- Prvi je agronom koji je postao član Srpskog učenog društva i prvi iz struke koji je bio počasni član Srpske kraljevske akademije (danas SANU).

- Prvi je, a zadugo i jedini, citiran srpski agronom u Evropi i SAD.

- Prvi je uveo bojene ilustracije u srpske agronomske knjige i časopise.

- Organizovao je tri prve poljoprivredne izložbe u tri srpska grada.

- Prvi agroinovator o čijim inovativnim delima postoje tragovi i dokumenti.

- Prvi je uveo u praksu gvozdeni plug i vršalicu sa vitlom.

- Prvi agroprosvetitelj koji je išao od mesta do mesta i držao poučna predavanja.

- Prvi je vršio meleženje ovaca i (prema biografiji na Vikipediji) uveo rasne guske iz zapadne Evrope.

- Prvi se zalagao za osnivanje poljoprivrednih škola na srpskom jeziku u Austro-Ugarskoj 
monarhiji, tj. u Kikindi i Srbobranu, koje nisu otvorene.

- Prvi je istraživao gajenje svilene bube u Srbiji.

- Prvi Srbin koji je izučavao poljoprivredu nekoliko zapadno-evropskih razvijenih država.

- Prvi je kolekcionar poljoprivrednih mašina, a potrudio se da bude i prvi inicijator uvoza mehanizacije u srpsku poljoprivredu (Savić, 2018).

- Po navodima Savić (2018), Radić je prvi uvezao simentalsku rasu goveda u Srbiju.

- Među prvima je postao član, ali i prvi sekretar Društva za poljsku privredu (DPP).

- Bio je prvi i jedini agronom čiju je zvaničnu biografiju objavila SANU.

- Bio je jedan od prvih vlasnika (izdavača i urednika) poljoprivrednog časopisa "Seljak", štampanog u Novom Sadu, Pančevu i Požarevcu (Mirić, 1992), koji je sa prekidima izlazio od 1862-1881. Osim toga, dve godine (1990 i 1991) je izdavao i časopis “Domaćin”, koji je imao podlistak 'Povrtar".

\section{Đorđe Radić kao prvi genetičar, selekcioner i semenar}

Prema mišljenju Mirića (2019), Đorđe Radić bio je prvi srpski, i jedan od prvih svetskih genetičara, selekcionera i semenara biljaka. Osnovao je prvo ogledno polje u bašti novosadske „Realke“ gde je vršio ukrštanja i hibridizaciju biljaka (Nedić, 2021). Prema Savić (2018), Đorđe Radić je bio prvi sakupljač sorti raznih biljaka, zapravo preteča banke gena. Prvi je preporučio sortu grožđa muskatni hamburg za uzgajanje kod nas.

Putujući u više navrata po Evropi, (Holandija), upoznao se, i prvi na srpskom jeziku opisao principe semenarstva: izolaciju semenskog useva i njegovo (biološko) plevljenje, kao i kategorije semena (Mirić, 1998). Prvi se u Srba bavio genetikom, o čemu piše Borojević (1986): '...u isto vreme sa Mendelovim otkrićem dr Đorđe Radić je otkrio odnos razdvajanja 1:1 u potomstvu jedne biljke kukuruza ljuskavca kao kod F1 generacije povratnog ukrštanja”. Rekorder je i po broju u praksu uvedenih sorti poljoprivrednih biljaka i rasa domaćih životinja. Bio je preteča uvođenja uređaja za doradu semena, poglavito trijera, kao i samovezaćica, vršalica i druge tehnike.

Dr Đorđe Radić je prvi srpski agronom koji je citiran u svetu, čak i u SAD, naročito njegov opis heterotičnog efekta kod kukuruza. On je 1855. g. posejao 500 "vrsta" krompira i našao da 12-20 njih imaju različito ime, a iste osobine. Godine 1874. počeo je proučavati sortne osobine različitih vrsta kukuruza plevičara i tvrdunca. Svoje kreacije, (sorte i rase), kao i mnoge proizvode (poput pamuka i vune), slao je na svetske izložbe u Anvers i Pariz krajem 19. stoleća i za njih dobijao nagrade.

\section{U čemu se još isticao Đorđe Radić}

Dr Đorđe Radić isticao se i svojim sledećim aktivnostima:

- Bio je jedan je od osnivača (1869) i prvih čelnika DPP, jednog od dva prva strukovna društva u Srba koja su dala veliki doprinos razvitku poljoprivrede.

- Bio je a može se reći i ostao najsvestraniji agrarni pisac među Srbima.

- Napisao je brojne udžbenike i priručnike za poljoprivrednike, odnosno za svaku važniju delatnost biljne i stočarske proizvodnje makar jedno, a često i više dela.

- Sudeći po njegovom veoma raznorodnom spisateljskom opusu bio je izuzetno svestran autor.

- Radićeve knjige i listovi koje je pokretao i uređivao štampani su u velikim tiražima, čak do 5.000 primeraka.

- Među srpskim agronomima bio je jedan od najaktivnijih članova više naučno-stručnih udruženja u Evropi i SAD (67 poljoprivrednih i kulturnih društava, među kojima su i tri američka).

- Dr Đorđe Radić je (Mirić, 2016) bio najobrazovaniji i najveći poljoprivredni stručnjak i naučnik u posle-ustaničkom periodu Srbije do polovine 20. veka.

- Rekorder je po broju poljoprivrednih i šumarskih škola koje je osnovao i u njima predavao.

- Bio je izuzetno vredan i koristan rodoljub, koji je po sirotim provincijama još nepriznatih država Srbije i Crne Gore otvarao škole, pokretao časopise i išao "od sela do sela" kao 
prosvetitelj. Hvala svima sličnim njemu koji su "Sebe davali celog" (Nedić, 2021) za napredak srpskog društva. Nažalost, čini se da takvih ili sličnih ljudi danas nemamo mnogo.

\section{Đorđe Radić je po mnogo čemu bio jedinstven}

Radić je verovatno jedini agronom koji je tri puta penzionisan i ponovo aktiviran, što je, zapravo, bio hir (smene) stranaka na vlasti. Bio je jedini autor (Savić, 2018) više od 50 knjiga, nešto manje poljoprivrednih kalendara i preko 550 članaka. Napisao je monografije o gajenju: pšenice, kukuruza, pivskog ječma, pamuka, krompira i jagode, udžbenike i priručnike iz voćarstva, cvećarstva i livadarstva, zatim je pisao o uzgoju i bolestima živine, knjigu o gajenju povrća i o đubrenju. Tek posle sto godina od Radićeve smrti pojavile su se kolege koje su objavile isti broj članaka ili knjiga koliko i on.

Đorđe Radić je bio najveći u mnogo čemu. Otvorio je više poljoprivrednih i šumarskih škola, napisao je brojne knjige, čija tematika do tada nije uopšte razmatrana. Evo toga spiska: Plug od postanka njegovog do danas; Uputstvo $k$ pravom poljodjelstvu za narod srpski (Sveska 1-3); Vođa pri gazdovanju srpskom narodu; $\mathrm{Pa}$ muk; Domaći živinarski lekar; Gajenje poljskih useva; Sve o pšenici; Gajenje pernate živine; Sve o kukuruzu; Očenje ili kalemljenje listom; Povrtarstvo za školu i narod; Nauka o zemljodjelstvu; Krompir; Jagoda; Livadarstvo; Povrtar; Gradinarstvo; O gajenju i nezi cveća; Nauka o zemljodjelstvu (2. popravljeno izdanje); Poljoprivredna čitanka; O proizvodnji ranog povrća u toplim lejama; O gajenju pivarskog ječma; Poljoprivredna čitanka; Đubre i đubrenje; Naše otrovne zmije i biljke; Voćarstvo; Moja 50-godišnjica književnog i kulturnog rada na unapređenju srpske poljske privrede 1861-1911.

Napomena: Iz spiska bi jedino mogli izostaviti knjigu izdatu 1878. g. (Povrtarstvo za školu i narod), budući da je tu materiju već delom sadržala ranije objavljena knjiga "Baščovan" $\mathrm{P}$. Bibića (1856).

Savić (2018) piše o ključnom doprinosu Đorđa Radića urbanizaciji Kraljeva, tj. tranziciji ovoga mesta iz varošice u grad, na čijem je čelu proveo godine Velikog rata, spašavajući ga od jarosti nemačkih zavojevača, savršenim poznavanjem nemačkog jezika i kulture.

Takođe se može prihvatiti ocena Milanovića (2019), da je Radić veliki agroekonomista, prosvetitelj, publicista i da neke njegove misli imaju vrednost i danas.

\section{Dvostruko ogrešenje o dr Đorđa Radića}

Zanemarivanje i nipodaštavanje svojih velikana već je prilično oveštala istina o srpskom narodu, a to nije mimoišlo ni dr Đorđa Radića. Pored toga što je predugo bio pod velom sveopšteg zaborava, pre i za vreme diktatorskog socijalizma, ogrešenje je nastalo u dva pokušaja da se otrgne iz tog mraka. Greške su nastale u dve "večne knjige" pa ovo nisu tek puke omaške. Naime, osim što je bio zaboravljen od 1922-1966., prvi trag o Radiću nalazimo u "Maloj enciklopediji" izdavačkog preduzeća Prosveta (Beograd, 1968, str. 399, II knjiga), koja je objavila manju (znači oskudnu), a uz to delom i netačnu odrednicu o Đorđu Radiću. Taj tekst glasi: 'Radić Đorđe (1839-1922), voćarski stručnjak, osnivač poljoprivredne škole u Kraljevu; objavio je veliki broj stručnih članaka i prvu srpsku pomologiju (voćarstvo)."

Nažalost, ta bezmalo ista, nedostatna odrednica je četiri decenije docnije uveliko preštampana u 'Enciklopediji srpskog naroda” (Beograd, 2008, str. 917), čiji je izdavač bio Zavod za udžbenike iz Beograda. Međutim, taj tekst je nešto kraći od prvog budući da i na taj način pokušava da zabašuri plagijat, a glasi: 'Radić, Đorđe (1839-1922), stručnjak za voćarstvo, osnivač poljopr. šk. u Kraljevu. Objavio je mnogo stručnih članaka i prvu srpsku Pomologiju”. Šta reći? Radić nije poglavito bio voćar (Dugalić i Jovanović, 2021), mada mu to spočitavaju autori gornjih enciklopedijskih odrednica! Oni pišu nedostojno o izuzetnom velikanu srpske kulture, a da pritom ne navode ni gde je rođen i šta je zapravo radio taj nesebični delatnik, već nešto, jednom površno napisano, preštampaju uz skraćenja reči i tobožnje izmene. Inače, te 2008. godine bilo je bar 20 temeljnih izvora o radu, raznovrsnosti opusa i veličini ličnosti Đorđa Radića. Ali, trebalo 
je te podatke potražiti, a ne pogrešne prepisati, odnosno poveriti zadatak onima koji bi to na dostojanstven način uradili.

Dakle, videli smo u ovom štivu da se erudita i rizničar agro-znanja Đorđe Radić pretežno bavio zeljastim (ratarsko-povrtarskim), a ne drvenastim biljkama ("voćarstvo", "pomologija"). Još manje se bavio vinovom lozom, ali treba ponoviti da je on imao najšire moguće interesovanje, jer skoro da nije zanemario ni jedno stanovište niti oblast agronomije.

\section{Umesto zaključka}

Ovo nedugo štivo nam ukazuje na izvrsnost dela dr Đorđa Radića, čime on zavređuje status pojedinca koji je zaloga vrhunskog srpskog identiteta, a pogotovo srpske agronomije. Bio je višestruko darovit, svestran, kulturni poslenik, vrsni pedagog i rodoljub ali i veoma preduzimljiv čovek, a ne samo teoretičar.

Ovaj svestrani pregalac ostaje doveka velikan male Srbije: istraživač (metodolog agronomskih ogleda u njivi i pod krovom), naučnik, pisac (različitih knjiga i članaka, čiji je bio ilustrator), prosvetitelj (idući od sela do sela), nastavnik, pokretač i urednik časopisa, osnivač škola, sekretar udruženja, član desetina udruženja (širom sveta), poliglota, planer poljoprivrede, ratar, semenar, genetičar, oplemenjivač biljaka (istraživač sortimenta, nagrađivan za "odnegovane sorte") i oplemenjivač stoke, stočar, mlekar, livadar, povrtar, voćar, biolog (botaničar i zoolog), veterinar, zaštitar, živinar, cvećar, primenjivač agroinovacija (novih sorti kulturnih biljaka i stoke, svilene bube i pčela (pčelar)), knjižničar, uvoznik agro-mehanizacije (mehanizator), savetodavac, kukuruzar, pšeničar, kalemar...

Pun ideja i njihov realizator $\mathrm{u}$ dve, tada srpske siromašne države $u$ nastajanju koje su se jedva i sporo izvlačile iz polumilenijumskog robovanja u hudoj balkanizaciji. A mogao je svuda u Evropi raditi i uživati, a ne lomatati se po Srbiji i Crnoj Gori. Tako radi rodoljub. Napisao je upravo toliko raznih udžbenika i priručnika koji su bili dovoljni za osnivanje poljoprivrednog fakulteta, iste 1906. g. kada je osnovan i Univerzitet u Beogradu. Dr Radić je bio najkorisniji srpski agronom bezmalo ceo jedan vek, budući da nije bilo drugog, a takvog, gotovo pola stoleća posle njegove smrti.

Inače, Đorđe Radić je bio vidno naklonjeniji zemljoradnji nego stočarstvu, verovatno ne stoga što njegovo ime "georgios" (grčki) znači zemljoradnik, već zato što je u to doba stočarstvo svuda, pa i u Srbiji, kaskalo za količinom pažnje koju je imalo ratarstvo.

Nažalost, Radić je po lošoj, srpskoj tradiciji, bio još za života skrajnut da se o njemu ništa nije čulo sledećih pola veka, kada mu "Savremena poljoprivreda" štampa zasluženu apoteozu (Pavićević, 1966). Zatim se na Radića osvrće i obimna knjiga: "100 godina Poljoprivredne škole u Kraljevu” (1983). Potom ga citiraju Borojević K. (1986) i Mirić (1992), a u SANU izlazi opširna biografija u ediciji "Život i delo srpskih naučnika" (Pavićević i Mijušković, 1996) koju je pokrenuo agronom Miloje Sarić, član SANU.

U tom smislu, umesno je predložiti da Savez poljoprivrednih inženjera i tehničara uvede godišnju nagradu za najbolji doktorat ili najvredniju agro-knjigu u protekloj godini koja će nositi ime "Dr Đorđe Radić". Takođe, valja osmisliti master temu kojom bi se iz bogate Arhive SANU i drugih izvora tačnije utvrdio broj članaka koje je objavio dr Đorđe Radić kao i šta je u njima suštinski sadržano. Nadalje, valjalo bi utvrditi na kojoj je temi Đorđe Radić doktorirao, naći i prevesti doktorat i objaviti ga na ćirilici. Inače, pisac ovog članka pretpostavlja da je tema njegove disertacije mogla biti iz domena istorijata pluga.

Trebalo bi videti kako su se u Kraljevu odnosili prema njegovim senima, a kako su se naša država i naša agrarna udruženja i fakulteti poneli prema prvom srpskom doktoru agronomskih nauka, svetskom čoveku. Sve navedeno je zarad ideje da bi dr Đorđu Radiću negde u Srbiji trebalo sagraditi dostojno obeležje (spomenik) kako bi se to mesto udostojilo poseta u budućnosti za odavanje zaslužene počasti ovom gorostasu srpske i svetske agronomije.

Isto tako, bilo bi korisno da se sačini objedinjavajuća publikacija nevelikog obima koju bi trebalo prevesti i objaviti od strane FAO u 
Rimu, kao štivo koje će doći do svih članica ove institucije. Bilo bi uljudno prihvatiti da se to uradi povodom stogodišnjice smrti 2022. godine.

U znak sećanja, valjalo bi da se i dvestogodišnjica Radićevog rođenja 2039. godine prigodno obeleži u agrarnim institucijama Srbije.

Ovim štivom autor je uvažio poruku Đuzepe Mazinija, koja glasi: 'Ne zaboravite da je prvi uslov nastanka velikana - da ih poštujete i kada su u rajskom vrtu”. U tom pogledu ovaj autor se stidi propusta i omaški koje su učinili lenji i neodgovorni prema vrednom i prilježnom naučnom i strukovnom pretku. Dr Đorđe Radić to nije zaslužio.

\section{Literatura}

Bibić P (1846): Baščovan. Pismeni kral. Sveučilišta peštanskog, Budim, s. 208.

Borojević K (1986): Geni i populacija. Forum, Novi Sad, str. 545.

Dugalić G i Jovanović Ž (2021): Naučno stručni rad Đorđa Radića. Zbornik SANU: 35-49.

Grupa autora (1968): Mala enciklopedija. Prosveta, Beograd, str. 399, II knjiga.

Grupa autora (2008): Enciklopedija srpskog naroda. Zavod za udžbenike, Beograd, str. 917.

Milanović M (2019): Ekonomsko biografski vremeplov: kalendar ekonomskih velikana, Ekonomski institut Beograd, str. 304.

Mirić M (1992): Nastanak, razvoj i efekti semenarstva u Jugoslaviji. Doktorska disertacija, Poljoprivredni fakultet u Novom Sadu, str. 146.
Mirić M (1998): Semenarstvo kao izazov. Društvo selekcionera i semenara Srbije i Institut za kukuruz 'Zemun Polje”, Beograd, str. 185.

Mirić M (2016): Agroevolucija (bibliofilsko izdanje). Izdavač autor, str. 815.

Mirić M (2019): Agroevolucija (prošireno izdanje). Izdavač autor, str. 1157.

Nedić N (2021): Đorđe Radić - Život, rad i prosvetiteljstvo. Zbornik SANU, s. 11-34.

Pavićević Lj (1966): Dr Đorđe Radić - Svijetli lik naše kulturne prošlosti. Savremena poljoprivreda, br. 9, Novi Sad.

Pavićević Lj i Mijušković M (1996): Đorđe Radić (1839-1922). 'Život i delo srpskih naučnika”, SANU, s. 95-128.

Radić Đ (1861): Plug od postanka njegovog do danas : S' dodatkom “Zašto se kod nas slabo noviji plugovi uvode?” U N. Sadu, brzotisak Episkopske knjigopečatnje.

Savić M (2018): Dr Đorđe Radić (1839-1922) prvi Srbin koji je stekao doktorat iz poljoprivrede. XXIII savetovanje o biotehnologiji, Agronomski fakultet Čačak, Zbornik radova, str.603-615.

Vikipedija: Odrednica - biografija dr Đorđa Radića. Dostupno na https://sr.wikipedia.org/sr

Primljen: 14.06.2021. Prihvaćen: 11.10.2021. 